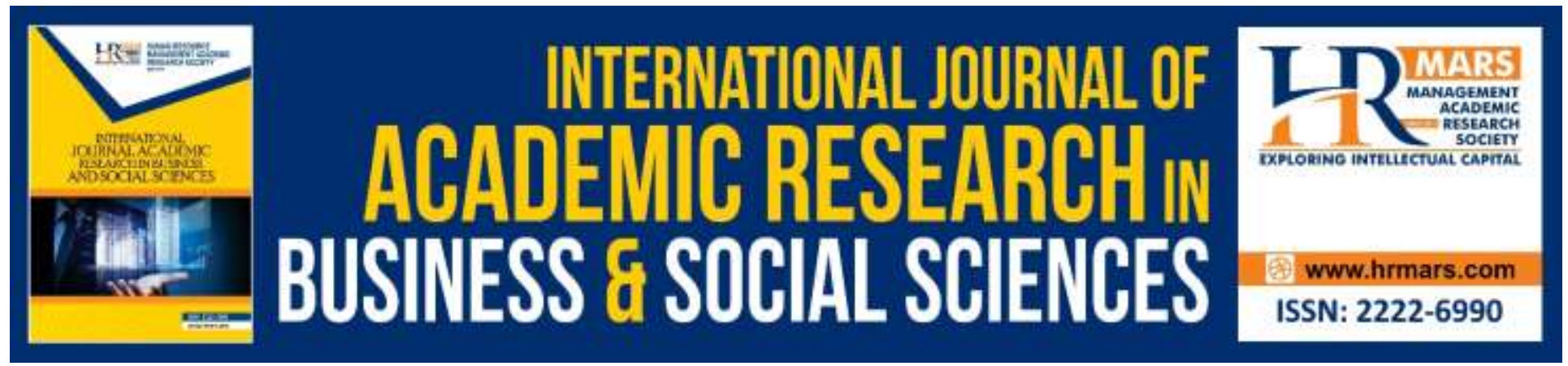

\title{
Implementation of Ithbait in Maqasid Al-Syari'ah as an Islamic-Based Research Method
}

\section{Azie Zurianie Mat Zaid, Wan Mohd Khairul Firdaus Wan Khairuldin}

To Link this Article: http://dx.doi.org/10.6007/IJARBSS/v9-i11/6676

DOI: 10.6007/IJARBSS/v9-i11/6676

Received: 11 October 2019, Revised: 29 October 2019, Accepted: 13 November 2019

Published Online: 30 November 2019

In-Text Citation: (Zaid, \& Khairuldin, 2019)

To Cite this Article: Zaid, A. Z. M., Khairuldin, W. M. K. F. W. (2019). Implementation of Ithbait In Maqasid AlSyari'ah as an Islamic-Based Research Metho. International Journal of Academic Research in Business and Social Sciences, 9(11), 1317-1325.

Copyright: (C) 2019 The Author(s)

Published by Human Resource Management Academic Research Society (www.hrmars.com)

This article is published under the Creative Commons Attribution (CC BY 4.0) license. Anyone may reproduce, distribute, translate and create derivative works of this article (for both commercial and non-commercial purposes), subject to full attribution to the original publication and authors. The full terms of this license may be seen at: http://creativecommons.org/licences/by/4.0/legalcode

Vol. 9, No. 11, 2019, Pg. 1317 - 1325

http://hrmars.com/index.php/pages/detail/IJARBSS

JOURNAL HOMEPAGE

Full Terms \& Conditions of access and use can be found at http://hrmars.com/index.php/pages/detail/publication-ethics 


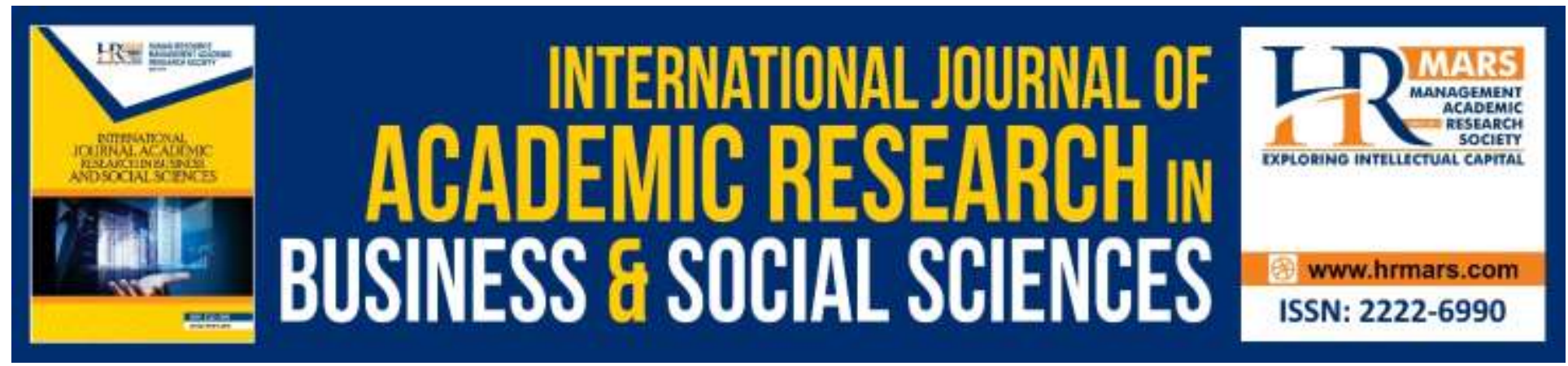

\title{
Implementation of Ithbait in Maqasid Al-Syari'ah as an Islamic-Based Research Method
}

\author{
Azie Zurianie Mat Zaid ${ }^{1}$, Wan Mohd Khairul Firdaus Wan \\ Khairuldin² \\ ${ }^{1}$ Faculty of Islamic Contemporary Study, Universiti Sultan Zainal Abidin, Gong Badak Campus, \\ 21300 Kuala Nerus, Terengganu, Malaysia, ${ }^{2}$ Associate Professor, Department of Syariah, Faculty \\ of Islamic Contemporary Study, Universiti Sultan Zainal Abidin. \\ Email: azie.mzm94@gmail.com
}

\begin{abstract}
Issues of Islamic-based research methodology have initiated discussions in global research recently. The problem that arises is the lack of social research methods in the study of Islamic science and Muslims, which include analytical and epistemological tools in social research methods. Epistemologies and analysis tools that do not meet Islamic law cannot be used to study Islam and Muslims. Therefore, the purpose of this article is to develop a framework model using the ithbat method in the knowledge of Maqasid Al-Syari'ah to be applied as an Islamic-based research method. The first objective of this study is to identify the method of ithbat in Maqasid Al-Syari'ah in determining Islamic law. Second, to analyze the method of ithbat in Maqasid AlSyari'ah as a method of Islamic research. The research design for this study is exploratory. The data collection method used is through documentation. The data analysis methods used are content analysis and method of difference. The first analysis of the study is taqyim which has been adapted to the technique of the research objective. The second is the istiqra 'process adapted to the inductive data analysis method. The results of this study conclude that the ithbat method of istiqra 'and taqyim in Maqasid Al-Syari'ah can be applied as a method of Islamic-based research. It is hoped that the implications of this study will help the public to better understand the true concept of Maqasid Al-Syari'ah and to realize the development of the Islamic-based research methods model in the future.
\end{abstract}

Keywords: Ithbat, Maqasid Al-Syari'ah, Islamic-Based Research Methods 


\section{Introduction}

The science of research methods is not new, but it has been widely studied since the 1960s. This knowledge has been fundamental in solving problems and solving current issues through a structured and systematic method (Ayob, 2005). In the meantime, Islam has provided guidance to Muslims in developing new forms of knowledge and methods based on the revelations of the Qur'an and the Sunnah.

In addition, al-Sunnah is also a source of revelation as a guide to the problems that are difficult to interpret in the Qur'anic verses. Instead, problems related to fiqh ibadat, muamalat, munakahat and various other fields of knowledge can be easily understood and resolved by scholars. This is because al-Sunnah is an indirect revelation given by the Messenger of Allah (SAW) through the command of Allah SWT without any added detail (Khairuldin, 2014).

According to this statement, all current issues and issues related to Islam and Muslims need to be referred to the Qur'anic and al-Sunnah sources. This is included in the method of Islamic-based research. Therefore, the use of reason alone does not guarantee accuracy in any study, especially in Islamic and Muslim studies (Khairuldin, 2014).

Khan (1994) argues that the application of revelation in the construction of research methods is no longer a foreign theme. However, these methods require periodic updates to fit the current research style. This is due to the fact that the existence of Islamic based research methods has existed since the earliest days of Islam (al-Buțiy, 1990).

Khairuldin (2014) also agrees that the method of Islamic-based research has been around for a long time and this is evidenced by the method of solving Islamic law through the Usul al-Fiqh method. Through this method, every problem that requires law will be referred to as one of the methods in Usul al-Figh's knowledge. However, according to Majid (2005), this method has not yet been successfully applied in Islamic-based academic research methods from a social perspective.

This statement is the same as Safi (1998) and Aziz (2019) that methods in other Islamic sciences especially Usul al-Fiqh should be adopted and polished in the field of academic research. This is mainly in the field of Islamic research. This is in support of al-Buțiy's (1990) opinion that Muslims now need to reorganize and refine the knowledge and methods previously developed by scholars to suit the current language and style.

Given the reality of social research methods today, the need to collect and analyze data is done in a variety of ways and forms (Masri, 2005). Violation of the law to fulfill these two requirements should be avoided. This situation is also cited as an ethic that needs to be followed in conducting research (Yahaya, Hashim, Ramli, Boon \& Hamdan, 2007). 
In addition, the findings of non-Shari'a studies will have implications for the development of educational institutions, societies, families and individuals (Rahim \& Awang, 2006). Based on preliminary observations, the epistemology of Maqasid Al-Syari'ah appears to have space and a need for further explanation in-depth on the research method that has a Shari'ah direction.

\section{Methodology}

The design of this study uses exploratory type study. According to McNabb (2010) as well as Harun and Abdullah (2004), exploratory studies are conducted to develop a new theory through the evaluation of topics that are carefully studied. Therefore, this study will develop a new theory on the application of the ithbat in Maqasid Al-Syari'ah as an Islamic-based research method.

The data collection method used in this study is documentation. According to Dalhat (2015), the method of data collection should be tailored to the theme of the study as it will influence the findings of the study. The documentation for this study includes secondary sources such as traditional and contemporary figh books, theses, articles, journals and other printed materials.

Next, the data analysis method for this study is content analysis and method of difference (Method of Difference). The analytical method is used to understand the definition of ithbat in Maqasid Al-Syari'ah and the Islamic-based research method. Then the method of difference is used to see the difference between ithbat in the knowledge of Maqasid Al-Syari'ah and the field in social research. Next, the rules of the Maqasid Al-Syari'ah will be matched with several methods in social research to suit them.

\section{Result and Analysis of the Study Definition of Maqasid Al-Syari'ah}

Al-Raysuni (1995) and al-Yubi (1998) concur in explaining the meaning of Maqasid Al-Syari'ah as the purpose, desire and benefit contained in the law to safeguard human right. Al-Zuhaili (2001) and 'Alal al-Fasi (1966) explain Maqasid Al-Syari'ah's meaning as a secret behind every law contained in Islamic law. These four definitions explain the meaning behind Maqasid Al-Syari'ah as the purpose behind every inquiry that has benefits and advantages to mankind.

Mukhtar (2006) concludes that Maqasid Al-Syari'ah is a science that discusses the pitfalls, benefits and advantages of any Islamic law study. This problem not only limits the general law of fiqh but also covers the entire process of protecting religion, life, intellect, property and the human race. This purpose is to explain the confession in the form of slavery to Allah SWT and for the good of humanity in the world and the hereafter.

\section{The Process of Ithbat in Maqasid Al-Syari'ah}

Various methodologies and methods used by the ancient and contemporary scholars in identifying Maqasid Al-Syari'ah. The methodology for identifying Maqasid Al-Syari'ah behind 
each law is called ithbat and is different for every scholar (Mukhtar, 2006). The ithbat processes that have been identified are istiqra 'and taqyim.

\section{a) Definition of Taqyim}

Taqyim is the process of assessing a matter in detail by looking at the characteristics, circumstances and causes involved before making any decision (al-Syațibi, 2006). The word taqyim in Maqasid Al-Syari'ah is often combined with the words Maqasid Al-Asliyyah and Maqasid Al-Tabi'iyyah. Thus, taqyim in Maqasid Al-Asliyyah means to study the original maqasid behind the inquiry which is the original purpose of a law being created (Al-Buțiy, 1990). Whereas taqyim in Maqasid Al-Tabi'iyyah is a process similar to the taqyim in Maqasid Al-Asliyyah but differs from the point of view behind the ritual itself. This means that the taqyim in Maqasid AlTabi'iyyah is the process of assessing the purpose of the intercession to align and strengthen with the Maqasid Al-Asliyyah. This process reviews the purpose of law to obtain the original purpose behind a mediation. In other words, taqyim is a process of combining the Maqasid Al-Tabi'iyyah to reach the Maqasid Al-Asliyyah.

b) Definition of Istiqra

Al-Juwaini (1980) concludes that the term istiqra' according to the knowledge of Maqasid AlSyari'ah is the process of constructing a general method based on the specific juz'iyyah texts of the Quran, al-Sunnah, ljma and Qiyas. The process of istiqra' in the knowledge of Maqasid AlSyari'ah uses a simpler method of researching the laws of the juz'iyyah for the purpose of producing a general concept of legal methods or the benefit of new ones. As for the general concept of the legal method, the purpose of the knowledge of Maqasid Al-Syari'ah is to convince them of the purpose and intent behind each inquiry (al-Ghazali, 1983).

\section{Definition of Islamic-Based Research Methods}

According to Faridi (1994) and Salleh (2008), the Islamic-based research method is a scientific study conducted to solve an issue using Islamic sources. The issues and topics for the study to be conducted are not confined to issues of traditional Islamic knowledge. In fact, the discussion of the issues to be explored is broadened to other areas but still relevant to the Islamic context. The sources used are the Quran, al-Sunnah and ljtihad (Anwar, 1994; Faridi, 1994).

Salleh (2008) explains that one of the differences between the method of social research and Islamic-based research methods is its philosophy and epistemology. Islamic epistemology, which originates in the Quran and al-Sunnah, acknowledges that there is a ruling power in this world, namely Allah SWT. Epistemology in the method of social research, on the other hand, denies the concept of divinity and the existence of the supernatural Being without proof until that it can be proved by the senses (Hassan, 2014). This understanding is called positivism.

\section{a) Construction of Research Questions}

The construction of research questions is one of the important points of a study. The research questions are designed to be answered in the analysis of the study while achieving the objectives 
of the study. Taqyim in the knowledge of Maqasid Al-Syari'ah means the process of carefully evaluating Maqasid Al-Asliyyah (the original purpose of the study) to construct the Maqasid AlTabi'iyyah (the purpose of the study). According to al-Syațibi (2006), the process of taqyim began by examining the methods or problems of common law already existing in Islam. This process is careful and in order. This process aims at establishing new issues in branch laws and selecting only the same chapter for study (Ahmad al-Raysuni, 2009; Ofeimu, Ahmed, \& Kolawole, 2018; Alqatamin, 2018). Determination of the larger legal system (Maqasid Al-Asliyyah) is a reference to the newly studied minority law (Maqasid Al-Tabi'iyyah). Later, the benefits of each of these laws called Maqasid Al-Tabi'iyyah are combined with one method and the more common benefit which called as Maqasid Al-Asliyyah. In addition, various arguments from Islamic sources were referred to before the new method of this process was intended to completely avoid any contradiction with the Qur'an and the Sunnah.

This study looks at the similarities between the processes of taqyim in the science of Maqasid Al-Syari'ah with the methodology of research questions in Islamic-based research methods. The process of constructing a research question begins with the research objectives of the study. Then, the research questions are constructed to be answered in the research analysis section. In fact, this taqyim process is viewed more carefully and is suitable for developing research questions in Islamic-based research methods. In addition, this taqyim process has strict requirements so that the questions and objectives of the study that are to be achieved in a study do not conflict with the sources of the Quran and the Sunnah.

\section{b) Data Analysis Process}

According to Kumar (2011), the process of data analysis is one of the most important processes in a study. The main purpose of data analysis is to answer all the questions raised at the beginning of the study. One of the processes of data analysis is inductive analysis. This inductive study is conducted to develop a new theory. This study is also known as qualitative. This inductive study uses observation methods for the process of data collection (Creswell, 2003).

According to Mukhtar (2006), the process of istiqra' in the science of Maqasid Al-Syari'ah is a study of the problems in the branches of law in order to develop a greater legal method. The construction of this larger legal requirement is yet to be found in any part of the knowledge of Maqasid Al-Syari'ah. Finally, this larger method of law is called the new theory and will serve as a reference to the determination of smaller issues in the future. According to al-Ghazali (2000), the istiqra process is more concerned with the source used. The sources used must be in line with the Qur'an and the Sunnah. This process looks like an inductive data analysis process that is even more detailed in retrieving the legal data source intended to be studied. Therefore, this study looks at the appropriateness of the application of istiqra process in the ithbat of Maqasid AlSyari'ah to be used as a process for data analysis in Islamic-based research methods. 
INTERNATIONAL JOURNAL OF ACADEMIC RESEARCH IN BUSINESS AND SOCIAL SCIENCES Vol. 9, No. 11, November, 2019, E-ISSN: 2222-6990 @ 2019 HRMARS

\begin{tabular}{|c|c|}
\hline Social Research Methods & Islamic-Based Research Methods \\
\hline Construction of Research Questions & Taqyim \\
\hline Data Analysis Process & Istiqra' $^{\prime}$ \\
\hline
\end{tabular}

Figure 1. Analysis process of ithbat in Maqasid Al-Syari'ah from prespective of social research methods

\section{Conclusion}

Islamic-based research methods have gained the attention of researchers recently. This is because, in some cases, social research methods are seen to be unable to resolve some of the major issues and concerns regarding Islam and Muslims. Particularly the study on the issue of the creed that concerns the existence of the supernatural understanding that is obligatory for every Muslim. This statement does not deny the power of social research methods in resolving issues and problems that have been explored by past and present researchers. This study seeks only to present a new model framework in Islamic-based research methods to study issues related to Islam and Muslims to fit the Islamic epistemology of the Qur'an and the Sunnah.

Therefore, this study seeks to identify several methods in one of the areas of Islamic knowledge to be applied as a method of Islamic-based research. The method is called the process of Maqasid Al-Syari'ah. After researching and analyzing, this study looks at the theoretical relevance of some of the processes in the method of social research with the process of ithbat in Maqasid Al-Syari'ah. The taqyim process is adapted to the process of research questions. Whereas the process of istiqra' is adapted to the process of data analysis. Therefore, this study looks at the relevance of the application of ithbat in Maqasid Al-Syari'ah as a method of Islamicbased research.

\section{Acknowledgements}

This paper is founded on the research project of the Fundamental Research Grant Scheme FRGS/1/2019/SSI03/UNISZA/02/3 (Project No: RR337). Special appreciation is owed to Ministry of Higher Education Malaysia (MOHE) and Universiti Sultan Zainal Abidin (UniSZA) for sponsoring and supporting this research.

\section{References}

Al- Zuhayli, W. (2001). Usul al-Fiqh al-Islami.Beirut. Dar al-Fikr al-Mu'asir

Al-Buțiy, M. S. (1990). Azmat al-Ma'rifah wa 'llajuh fi Hayatina al-Fikr al-Mu'asirah. DIm. alManhajiyyah al-Islamiyyah wa al-'Ulum al-Sulukiyyah wa al-Tarbawiyyah. Jordan: alMa'had al-'Alami li al-Fikr al-Islami.

Al-Fasi, A. (1966). Maqasid Al-Syari'ah al-Islamiyyah wa Makarimuha. Rabat: Mațabi' al-Risalah. Al-Ghazali, M. (1983), Al-Mustashfa min ‘llm Al-Ushul, Juz I, Beirut, Dar Al-Kutub Al-IImiyyah. Al-Juwaini. (1980), Al-Burhan fi Ushul Al-Fiqh, Beirut, Dar Al-Kutub Al-Ilmiyah. 
Al-Khadimi, N. D. (2006). 'Ilm al-Maqasid al-Syar'iyyah. Riyadh: Maktabat 'Ubaikan

Alqatamin, R. M. (2018). Capital Structure and CEO's Personal Characteristics: Evidence from Jordan, International Journal of Academic Research in Accounting, Finance and Management Sciences 8 (2): 113- 125.

Al-Raysuni, A. (1995). Naz̧ariyat al-Maqasid 'inda al-Imam al-Syațibi. Virginia.

Al-Raysuni, A. (2009). Madkhal Ila Maqasid Al-Syari'At. Kaherah: Dar alKalimah.

Al-Syațibi, I. (2006). Al-Muwafaqat. Kaherah: Dar Ibn 'Affan.

Al-Yubi, M. (1998). Maqasid Al-Syari'ah al-Islamiyyah. Riyadh: Dar al-Hijrah li an-Nasyr wa alTauzi'. The International Institute of Islamic Thought.

Anwar, M. (1994). "Research Methodology in Islamic Perspective", dalam Mohammad Muqim (ed), Research Methodology In Islamic Perspective. New Delhi: Institute of Objective Studies.

Ayob, A. M. (2005). Kaedah Penyelidikan Sosioekonomi. Kuala Lumpur: Dewan Bahasa dan Pustaka

Aziz, N. S. A. (2018), Aplikasi Konsep Mutawatir Dalam Ilmu Qiraat Sebagai Kaedah Penentu Kesahan Dan Kebolehpercayaan Data Dalam Kaedah Penyelidikan Berteraskan Islam. Universiti Sains Malaysia 2018.

Corporation.

Creswell, W. (2003). Research Design: Qualitative, Quantitative, and Mixed Methods Approaches. California: SAGE Publications.

Dalhat, Y. (2015). Introduction to Research Methodology in Islamic Studies. DIm. Journal of Islamic Studies and Culture. Kaduna State: Nigeria.

Faridi, F. R. (1994). "Islamic Research Methodology: Some Reflection”, dalam Mohammad Muqim (ed), Research Methodology In Islamic Perspective. New Delhi: Institute of Objective Studies.

Harun, A. \& Abdullah, N. (2004). Metodologi Penyelidikan untuk Ekonomi dan Sains Sosial. Singapura: Thomson and Learning.

Hassan, S. A. (2014). Aplikasi Kaedah Penaakulan Mantik Dalam Penyelidikan Berkaitan Islam. Pulau Pinang: Universiti Sains Malaysia

Khairuldin, W. M. K. F. W. (2014). Aplikasi Proses Penfatwaan Dalam Kaedah Penyelidikan Berteraskan Islam. Pulau Pinang: Universiti Sains Malaysia.

Khan, I. A. (1994). The Islamic Method. in. Muqim, M. (ed), Research Methodology In Islamic Perspective. New Delhi: Institute of Objective Studies.

Kumar, C. (2011). Research Methodology. New Delhi: APH Publishing

Majid, M. Z. (2005). Pengajian Usul al-Fiqh Sebagai Kaedah Penyelidikan Hukum. DIm. Jurnal Syariah, Bil. 12, No. 2. Kuala Lumpur: Jabatan Fiqh dan Usul, Universiti Malaya.

Masri, S. (2005). Kaedah Penyelidikan dan Panduan Penulisan (Esei, Proposal, Tesis), cet. 2. Kuala Lumpur: Utusan Publications \& Distributors Sdn. Bhd

McNabb, D. E. (2010). Research Methods for Political Science: Quantitative and Qualitative Approaches. New York: M. C. Sharpe Inc. 
Ofeimu, J., Ahmed, E. S., \& Kolawole, B. O. (2018). Influence of Principals' Sex, Experience and Age on their Choice of Leadership Style in Managing Students' Indiscipline in Public Secondary Schools in Edo North Senatorial District of Nigeria. International Journal of Academic Research in Progressive Education and Development, 7(1), 12-23.

Safi, L. (1998). Asas-asas ilmu pengetahuan: Satu kajian perbandingan kaedah-kaedah penyelidikan Islam dan Barat. Selangor: The International Institute of Islamic Thought \& Thinker's Library Sdn. Bhd

Salleh, M. S. (2008). Kaedah Penyelidikan Berteraskan Islam: Keperluan, Kedudukan dan Hala Tuju. Pemikir, Bil. 54, Oktober-Disember. hlm. 133-164. Diterbitkan Semula Dalam Siri Kertas ISDEV No. 8

Yahaya, A., Hashim, S., Ramli, J., Boon, Y. \& Hamdan, A.R. (2006). Menguasai Penyelidikan Dalam Pendidikan: Teori, Analisis dan Interpretasi Data, Cet. 1. Kuala Lumpur: PTS Professional Publishing Sdn. Bhd. 